\title{
Training teachers to integrate technology: Drawing parallels between fluent (L2) and foreign language (EFL) users of English
}

\author{
Mohammad Imran Khan, Department of English Language, College of Arts and Sciences, Methnab Qassim \\ University, Saudi Arabia, mi.khan@qu.edu.sa
}

\begin{abstract}
The present study ascertained the impact of technology integration in the L2 classroom using the Technological Pedagogical Content Knowledge (TPACK) for student teachers and using the implications in EFL settings. In simple words, TPACK means the readiness, both in terms of attitude and knowledge, of teachers to use technology in their classrooms. The study used a quasi-experimental approach, blending both quantitative and qualitative methods to collect data at state-run universities in India on the population of student teachers of English. It may be pointed out here that though English is the language most spoken by Indians, it is officially the second or even third language in most state schools. Yet, it is not a 'foreign language' but one of the official languages in the country. Therefore, the premise that findings in this study can be used in EFL settings as in KSA. The data for this study was collected using mixed methods which provides definitive and useful results. The TPACK scale results and interviews indicated a major increase in the overall TPACK self-efficacy of student teachers of English after participating in CALL. The change was noticeable in TPACK's technology-related domains. This study generally demonstrates that TPACK CALL preparation holds great promise for students training to be English teachers and the incorporation of CALL into ELTEPs in L2 and EFL settings is highly recommendable. Also, after engaging in CALL workshops, student teachers' TPACKLanguage self-efficacy increased. It can be suggested on the basis of the findings of this study that while CALL integration is paramount in ELTEPs, many student teachers need various hands-on opportunities and a kind of internship to promote their self-efficacy with TPACK-English to be in a better position to use technology correctly and efficiently inside language teaching.
\end{abstract}

Keywords: Technology, English Classroom, TPACK, Language Learning, Student Teachers

Received: 04.12.2020 $\quad$ Accepted: 23.01.2021 $\quad$ Published: 02.02.2021

\section{INTRODUCTION}

There is an increasing interest in the integration of technology into teaching. The rapid and irrevocable advancements in computer technologies have made it possible for individuals around the globe to communicate, bridge cultural gaps, do business, and enjoy learning (Alotumi, 2020; Pegrum, 2014; Al-Ahdal \& Algasham, 2020). Their position in all areas of knowledge and training programs, particularly in language education, have been strongly established (Kessler, 2018). This leads to a test as to how future language teachers can prepare themselves in using advanced technologies in their teaching making their teaching environment engaging, innovative and most importantly, effective (Kessler \& Hubbard, 2017).

In order to provide necessary intervention to address the issue of technology integration into language teaching pedagogy, Misha and Koehler (2006) introduced the Technological Pedagogical Content Knowledge (TPACK) which can be adopted by teachers for them to know the necessary technology applicable for their teaching process. According to Bostancioğlu \& Handley (2018), TPACK is focused on the theoretical foundations which will explain the teachers' knowledge and skills in integrating the use of technology in education.

Shulman's (2016) construct of Pedagogical Content Knowledge (PCK) where TPACK was based, explained that it is important for teachers to understand and know the relationships between pedagogy, content, and technology so that the effective integration of technology in teaching can be successfully achieved (Koehler et al., 2017). The first domain is Content Knowledge (CK) being the body of knowledge under the subject matter which the teacher will share with the students. The second domain is the Pedagogical Knowledge (PK) which focuses on methods in teaching knowledge. The third domain is Pedagogical Content Knowledge (PCK) that talks about knowledge in merging content (subject matter) and pedagogy (methods of teaching) in order to advance the teaching practices in content areas. The fourth 
domain is Technology Knowledge (TK) which includes knowledge on the application of various technologies that started from non-technology such as paper and pencil to digital technologies such as computer applications, internet, and other interactive means of technological knowledge. Technological Content is the fifth domain that deals with technology utilization as a tool in presenting specific content. The sixth domain is Technological Pedagogical Knowledge (TPK) which tells about the proper utilization of varying technologies in teaching. The last domain is the Technological Pedagogical Content Knowledge (TPACK) which requires a teacher to know how to effectively use or integrate technology in teaching a subject matter that will promote a student-centered environment.

The English Language Teacher Education Program (ELTEP), through the adaption of TPACK suggests the use of technology related courses such as computer and educational technology course providing the student-teachers with technical knowledge of computer software and hardware including the technologicalpedagogical knowledge of using varying technology tools in their teaching. Through the use of ComputerAssisted Language Learning (CALL), language teachers are targetted to be equipped with the advanced technologies considering that the world is now in a digital era. Kessler and Hubbard (2007) averred that there is really a need for teachers to become knowledgeable with computer-assisted language learning principles and practices in order to be able to adapt it to their own classroom. Rahimi and Pourshahbaz (2019), and Son (2018) believed that employing CALL in the classroom cannot be possible if the teacher doesn't have the necessary knowledge and skills in integrating technology in instruction. Hence, the ELTEP encourages the integration of CALL across all curriculum (Fathi \& Ebadi, 2020; Mei et al., 2017; Murray, 2017; Park \& Son, 2020).

The ELTEP is responsible for equipping the EFL teachers with knowledge in TPACK in teaching English by integrating Computer-Assisted Language Learning (Baser et al., 2015; Bostancioğlu \& Handley, 2018; Fathi \& Ebadi, 2020; Joo et al., 2018; Pegrum, 2014; Son, 2018; Rahimi \& Pourshahbaz, 2019; Tai, 2015; Torsani, 2016; Turgut \& Boylan, 2017; Kitishat, Omar \& Al Momani, 2020; Alfallaj, 2020; Luanganggoon, 2020; Al-Ahdal, 2020). Based on the definition of Beatty (2010), CALL means learner's utilization of a computer which will boost the learner's proficiency in the language. With these, the implementation of CALL Project is necessary for ELTEP in the different public universities to engage L2 student teachers of English in a formal CALL training which will also boost their confidence to teach the language in a technology enriched future.

\section{TPACK Self-Efficacy: The Background}

Bandura (1994) defines perceived self-efficacy as the 'beliefs of a person about their ability to produce designated levels of self-efficacy output that influences events that impact their lives". Self-efficacy of Teachers refers to the personal convictions of teachers regarding their experience and skills in pedagogy. Instructor conduct (Kent \& Giles, 2017), the learning habits of student teachers (Koh, 2011), as well as their degree of learning anxiety or levels of trust are reliable measures of self-efficacy. TPACK self-efficacy refers to the personal opinions of teachers about their ability to successfully incorporate technology in their teaching (Baser et al., 2015; Bostancıoğlu \& Handley, 2018; Setyowatiati Ciptaningrum, 2017; Tai, 2015; Rahimi \& Pourshahbaz, 2019).

Analysis of studies have assessed the value of positive views of TPACK self-efficacy on the success of teachers in the integration of technology in their teaching (Joo et al., 2018; Koh \& Chai, 2014; Mei et al., 2017; Tseng et al., 2019). Studies have further shown that teachers with higher self-efficacy in TPACK Technology were more likely to use technology in their preparation (Joo et al., 2018; Kartchava \& Chung, 2015; Teo \& Chung, 2015).

Evidently, the expectations of student teachers in TPACK competencies are important for their potential use of CALL. If a portion of CALL is considered uncomplicated, teachers are more likely to have a stronger intent to use it (Ince, 2017; Joo et al., 2018). Conversely, if it is considered that the technology used is difficult, they are more likely to show resistance (Akayoğlu, 2017; Mohammadzadeh \& Salem, 2018). In this regard, Teo et al. (2018) stressed that the use of Web 2.0 technologies is conducive to a strong TPACK for purposes of instruction.

Chambers and Bax (2006), stressing the significance of EFL-TPACK CALL preparation, pointed out that the teachers' significant variables that have a negative effect on the normalization of CALL cause the absence of adequate instruction. Accordingly, Kessler and Hubbard (2017) indicated that teacher educators should have CALL competency first to ensure that CALL normalization can be feasible in teacher education. Likewise, Son (2018) stressed that one of the key objectives of language teacher education is to help student 
teachers improve their skills and abilities in CALL as more and more technology integration is becoming not only desirable, but also, a need of the hour.

To maintain positive expectations of their self-efficacy with TPACK and thus improve their use of technology, student appropriate CALL training should be given for teachers to improve their self-efficacy with CALL (Ersanli, 2016; Fathi \& Ebadi, 2020). In addition, teacher educators can use CALL regularly in their classrooms so that student teachers can be exposed to different CALL integration interactions (Kessler \& Hubbard, 2017; Mei et al., 2017; Park \& Son, 2017; 2020; Son, 2018). It is extremely significant, according to Kessler (2018), that formal teacher education involve proper means to provide future educators with the opportunity to use technology and to objectively improve their mindset towards use of technology for teaching and learning.

It has also been documented that the attitudes of teachers not only influence their personal choices and interactions with technology but also of their students (Admiraal et al., 2016; Hlas, 2017). And, as technology continues to evolve, student teachers, particularly in a technology-based setting, are rapidly making some applications redundant and thus outdated.

\section{Previous Studies on TPACK Self-Efficacy in ELTEPs}

Given the fact that English is used for official, commercial and personal purposes by a predominantly large number of Indians, some claiming it as their first, second or third language, it is certainly not a native tongue for them. Moreover, with learners getting introduced to the language even as they move from primary to middle school, their language exposure is almost at par with that of EFL learners in KSA. On the definitions and distinction between ESL and EFL, Omidvar \& Ravindranath (2017) have succinctly drawn the line by stating that in an EFL setting the language proficiency of the general population in English is much lower than that found in case of ESL. At the same time, studies in ESL are scarcer than studies in EFL settings. Even so, with new training needs brought about by recent global developments in the wake of the pandemic, schools incorporating smart boards and teacher consoles to remain tech savvy, and the administration favoring technology integration into educational curricula, teacher training needs too have undergone change. Moreover, it must be remembered that student teachers are the products of the current knowledge era and they are as much inseparable from their smart devices as their counterparts in other vocations. Hence the need for assessment of their TPACK competencies. These studies are almost unheard of in the L2 setting of India, which leads the current study to draw from EFL studies using TPACK.

While there are several studies focusing on the incorporation of TPACK in general teacher education, a few recent studies have been published. The effect of CALL integration on the perceived TPACK self-efficacy of EFL student teachers (CALL) has been investigated. For example, Akayoğlu (2017) looked into Turkish perspectives of EFL student teachers on a CALL course. He used the approach of content analysis to evaluate students' reflection on 14-week-CALL course blog entries. He found tha, after taking the CALL course, the anxiety of the participants and the standard of CALL had altered and they felt more positive about CALL instruments. Additionally, the participants mentioned that the CALL course should have been offered at an earlier grade of the undergraduate program. Ersanli (2016) examined the influence of a five-week workshop on the TPACK of EFL student teachers. A TPACK survey and journal entries were used to collect data from 59 Turkish state university ELTEP student teachers. The results of this study showed a statistically important change by using descriptive and inferential statistics. The study concluded that student teachers were positively disposed in the production and adaptation of language learning and teaching material and concrete targets using technology. In another study, Işler and Yıldırım (2018) analyzed the opinions of Turkish EFL student teachers regarding their TPACK competencies. The variables affecting the TPACK attitudes of student teachers and their interests in technology were also investigated as an integration to instruction at EFL. A TPACK questionnaire and interviews were used to gather data from 94 student teachers at ELTEP, a Turkish public university. Their results showed that participants had a satisfactory level of TPACK skills using descriptive statistics and content analysis. In addition, personal interest, experience, expertise, and access were found to influence factors associated with the creation of TPACK by student teachers. Joo et al. (2018) examined the expectations of EFL student teachers to explore structural relationships between TPACK, selfefficacy of teachers, perceived ease of use, perceived utility, and their intentions to use technology for purposes of guidance. A questionnaire was used to collect data from 300 student teachers at three Korean universities' colleges of education. Using the methodology of structural equation modeling, their results showed that the TPACK of student teachers influenced their perceived ease of use and perceived usefulness positively. A questionnaire was used to collect data from 300 student teachers at three Korean universities' 
colleges of education. Using the methodology of structural equation modeling, their results showed that the TPACK of student teachers influenced their perceived ease of use and perceived usefulness positively. Le and Song (2018) investigated the impact of a CALL course on the TPACK level of Vietnamese EFL student teachers and explored their attitudes to technology incorporation in language teaching. To gather data from a purposeful sample of $42 \mathrm{EFL}$ student teachers, they used pre-and post-surveys and semi-structured interviews. The results of their surveys showed that while there was a relative rise in the TK, TPK, TPACK of student teachers, this increase was not a substantial change in the TPACK of student teachers. Participants with more teaching experience were also found to feel more secure in their incorporation of TPACK into language instruction. In addition, educational policy, services, and their teaching philosophy were informed by the attitudes of the participants towards CALL integration. During their teaching practice at ELTEP in Indonesia, Prasojo et al. (2018) analyzed the impressions of ICT integration by EFL student teachers. They used qualitative analysis with a case study technique focusing on video-based research. Observations and focus group discussions for a study of $60 \mathrm{EFL}$ student teachers to gather data. Their findings showed that while participants had good level and experience of ICT competency and represented positive expectations of ICT benefits for EFL instruction, due to school circumstances, they did not use ICT in their teaching practices. The effect of background on the TPACK enactment of six EFL student teachers in Taiwan was explored by Tseng et al. (2019). They also aimed at explaining how, over the course of 14 weeks, student teachers considered contextual factors in applying web conference technology to EFL learning and teaching. Quantitative content analysis of coded post-teaching conversations and qualitative interview analysis were used by them. The results of their analysis showed that although the discussions of the participants were oriented towards PCK, their discussions were not especially correlated with TPK as compared to TK. In addition, their results showed that the two prominent contextual factors affecting the web-conferencing teaching of student teachers were quality technological problems and the doubts of teachers regarding their students' prior knowledge.

\section{Statement of the Problem}

ELTEPs (English Language Teachers Education Programmes) in India do not have a structured CALL course as part of their curriculum. Instead student teachers have two classes related to technology: a computer course and a course in educational technology. These courses are general and have little relevance to specific language teaching and may therefore not be necessary to improve their TPACK effectiveness as also noted for similar courses in other studies for EFL student teachers (El Shaban \& Egbert, 2018; Kessler \& Hubbard, 2017; Schmid, 2017; Son, 2018). Since recent studies have yielded mixed results on the effect of CALLoriented training on the self-efficacy of TPACK student teachers (Le \& Song, 2018; Tai, 2015), and since student perceptions are dynamic and influenced by the rate of change in self-efficacy of technology (Lai et al., 2014; Lee et al., 2011), this study investigated the perceptions of Indian prospective English teachers for their TPACK self-efficacy before and after the specialized training offered by CALL.

\section{Purpose of the Study}

The present study aims to investigate the impact of CALL on the effectiveness of Indian English langauge student teachers using the EFLL. The study uses a slightly modified version of the TPACK Self-Assessment Survey known as TPACK-EFL by Baser et al (2015). In line, the study explicitly focuses on the following research questions for this purpose:

1. What are the TPACK self-efficacy expectations of Indian English language student teachers before they received CALL training?

2. What are the impressions of the Indian English language student teachers of their post-CALL TPACK self-efficacy?

3. Is there any important difference in the perceived overall self-efficacy of TPACK pre and post CALL?

4. What are the attributions of Indian student teachers to their increased or decreased expectations of self-efficacy in TPACK so far as ELT is concerned?

\section{Research Hypothesis}

The following null hypothesis was generated based on the above questions:

H0: There is no substantial difference between the perceived overall pre and post CALL TPACK self-efficacy of English language student teachers in India. 


\section{METHODOLOGY}

As its participants have not been randomly assigned to the treatment, this descriptive study is of a quasiexperimental nature. It used a one-group pre-test-post-test model and employed a mixed-method methodology, i.e. a mixture of both quantitative and qualitative methods were used to collect data at state-run universities in India on the population of student teachers of English.

\section{Design of the Study}

A one-group pre-test-post-test design was implemented in the present research. Based on participants' selfreporting of their TPACK self-efficacy pre- and post-CALL, it employed a mixed-method approach in data collection.

\section{Participants}

Four hundred student teachers of English across three ELTEPs in India's capital New Delhi were included in the target population of this report. Since CALL was introduced in these institutions during the running academic session 2019-2020. Via systematic sampling process, one hundred participants from each institute were selected by selecting every second name from the teachers' roster. This yielded 400 homogeneous student teachers among the participants of the true representative sample $(\mathrm{N}=400)$. They responded to the same pre- and post-CALL questionnaire. Their mean age, ranging from 23 to 29, was 24. Sixty-five percent were women among the participants.

For qualitative results, based on their willingness to participate in semi-structured interviews, four male student teachers and four female student teachers were selected from those who replied to the questionnaire in each ELTEP. During the interviews, thirty-two student teachers were asked the same set of questions, with no space for further clarity on the spot questions.

\section{CALL Workshops}

The goal of this workshop was to familiarize participating student teachers with some of CALL's latest concepts and skills. For each institution in the study, five intensive English TPACK CALL workshops were organized (see Appendix A for the outline of CALL workshops). The student teachers were given the same CALL workshops by the same CALL trainer in each ELTEP (the researcher). Every workshop lasted 4 hours (with a 30-minute break) and followed the steps suggested in the model of TPACK-in-Action (Tai, 2013): (1) modeling; (2) analysis; (3) demonstration; (4) application; and (5) reflection (see Figure 2).

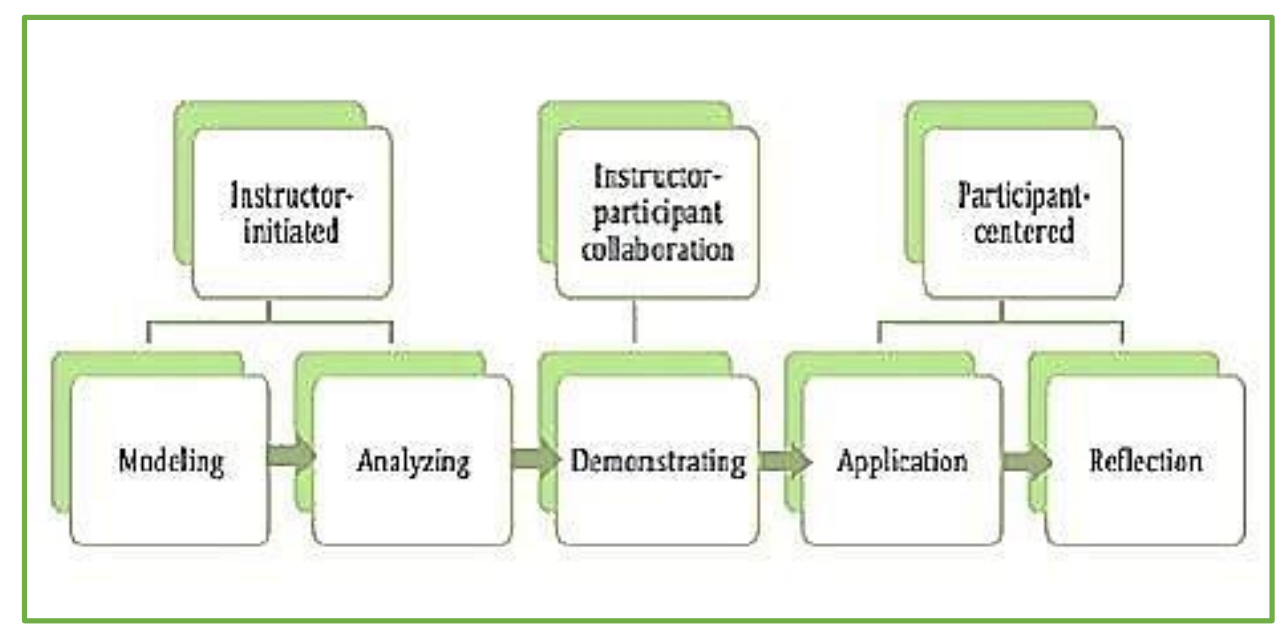

Figure 2. TPACK-in-action model adapted from Tai (2013).

\section{Instruments}

To gather data from the participants, two instruments were used: (1) a survey and (b) an interview. Two parts of the survey were (see Appendix B). The first one covered the demographic details of student teachers, 
including age, gender, and willingness to participate in a CALL interview. The second portion was a questionnaire adapted from the TPACK-EFL self-assessment developed by Baser et al (2015).

Seven subscales corresponding to TPACK's aforementioned components were included in the TPACK- questionnaire. It included 39 items (statements) of the Likert-type, ranging from strongly disagree = 1 , to disagree $=2$, don't know $=3$, to agree $=4$, to strongly agree $=5$. Items $1-9$ assessed the perceived TK selfefficacy of student teachers. Their perceived CK self-efficacy was measured by items 10-14. It was assessed using items 15- 20 with regard to their perceived PK self-efficacy. They were designed to assess the PCK selfefficacy of student teachers with respect to items 21-25, while items 26-28 evaluated their TCK self-efficacy. With reference to items 29-35, they were structured to measure the perceived TPK self-efficacy of student teachers. The last four items (items 36-39) looked at their self-efficacy with TPACK. The seven TPACK domains in the instrument acquired high internal reliability in terms of reliability (Cronbach's $>.80$ ) (Baser et al., 2015). Their perceptions of each subscale were assessed with a variety of possible mean scores (between 1 and 5) to determine the perceived self-efficacy of participants, with higher scores suggesting a higher degree of self-efficacy.

A semi-structured interview form was designed for the interviews, based on the expectations of student teachers of English about their TPACK self-efficacy (see Appendix C). The purpose of the interview was to substantiate the information collected by the TPACK-EFL survey. It also aimed to get the participants to share their views on CALL and their TPACK self-efficacy shift attributions.

This instrument was validated by experts and EFL student teacher feedback, and then by exploratory factor research, regarding the face validity and material validity of the TPACK-EFL survey (Baser et al., 2015). It was given to a panel of three professors of applied linguistics at a government University to analyze the validity of the items for the interview question type. Before carrying out the analysis, their informative input was used to delete, incorporate, and change the interview instrument items.

Cronbach's coefficient alpha value for all the items in the modified TPACK-EFL analysis ranged from .81 to .92 in terms of reliability (Baser et al., 2015), suggesting that the items were of high reliability (Cohen et al., 2018). Cronbach's alpha values for the TPACK-EFL survey subscales were .89 for TK (extremely reliable), .88 for CK (highly reliable), .92 for PK (very highly reliable), .91 for PCK (very highly reliable), .81 for TCK (highly reliable), .91 for TPK (very highly reliable), and .86 for TPACK (very highly reliable), according to Baser et al. (2015). (highly reliable).

\section{Procedures of Data Collection}

The researcher travelled to the selected institutions after seeking formal permissions form the concerned Heads of English Departments (HoEDs). The first week was spent conducting the CALL workshops in the institutions. The attendees of these workshops were also the respondents for the questionnaire. The researcher himself conducted both questionnaires with the assistance of HoEDs and timed them similarly (60 minutes). Therefore, the return rate and valid response rate were 94-97 percent for both questionnaires, suggesting a strong valid response rate (see Table $\mathrm{D}$ for each university response rate).

Those who indicated their willingness to participate in a CALL interview were allocated numbers after administering the post-CALL modified TPACK-EFL survey in each ELTEP and classified as per gender (male/female). Four male and four females were finally interviewed from each institute with each interview lasting 15-20 minutes and conducted in English. All interviews were electronically recorded on a smartphone after obtaining formal consent of the participants.

\section{Data Analysis Procedure}

Questionnaire information was analyzed using both descriptive and inferential statistics (see Table E). In order to define and summarize the data obtained from the study sample, descriptive statistics (mean and standard deviation) were used, while inferential statistics (paired-sample $t$ test and effect size) were used to make inferences about the population parameters using the sample data statistics (Cohen et al., 2018).

Since their perceived TPACK self-efficacy was tested twice by the modified TPACK-EFL pre- and postCALL questionnaire in the same group, the research technique used was a paired-sample t-test (Cohen et al., 2018). The paired-sample t-test examines whether the group's score distribution is significantly different. It relies on four key assumptions about the scores obtained (Cohen et al., 2018). The first assumption is the interval or ratio of the scores. The findings obtained in this analysis are obviously intervals. The second premise is that the scores are derived from mutually independent observations. In this analysis, during two separate sessions, pre- and post-CALL, the scores were obtained from the same group using the same 
instrument. The third premise is that such ratings are usually assigned. To examine whether the scores are roughly normally distributed, the Shapiro-Wilk Test was used. It showed that the paired sample scores do not vary significantly from a normal distribution-the Sig. value of the score difference between pre- and postCALL was greater than .055 on the exam (see Figure F1). The fourth premise is that no outliers should be contained in the scores. A sample scores boxplot visually showed that the study scores are without outliers (see Figure F2).

For the paired design suggested by Cumming, the effect size, defined as an estimation of effect magnitude in the population, was calculated in line with "Formula 11.10" (2012, p. 291). According to Cohen's (1992) suggested guidance, the outcome of the effect size equation, stated at the significance level of 0.05 , was interpreted in such a way that $r=.10$ is small effect size, $r=.30$ is medium effect size, $r=.50$ is big effect size.

According to the suggested guidelines for the coding process, Creswell and Creswell (2018) analyzed the qualitative data collected through the interviews. Correspondingly, for the 32 interviewees, all recorded interviews were simply transcribed, using anonyms. Next, an in-depth reading of all the transcripts was completed in order to assort the answers in the light of questions from the report. Then, codes were analytically evolved using repeated words, phrases, patterns, and notions within each category. Those codes were subsequently identified into coding groups, with related codes being translated into wider categorical themes.

Both quantitative data analyses were performed to evaluate the relationships between the independent variable and the dependent variables using the Statistical Package for Social Sciences (SPSS) version 20. An alpha level of 0.05 has been used by convention as the standard for statistical significance. The data from the interview was analyzed using MAXQDA (v. 11), a software framework for qualitative data analysis.

\section{FINDINGS}

\section{Findings from the Survey}

In order to answer the first and second research questions, answering the expectations of student teachers of their modified TPACK pre and post CALL self-efficacy, descriptive statistics were employed to show the mean and standard deviation of the responses of the participants to the two questionnaires. The mean and standard deviations for the pre- and post-CALL TPACK and TPACK-EFL domains are recorded in Table 1, while the score category breakdown used in the mean level interpretation is provided in Table 2.

As shown in Table 1, the perceived overall pre-CALL modified TPACK self-efficacy level of the respondents was moderate with an overall mean score of $3.37(\mathrm{SD}=0.83$ ), while their perceived overall postCALL modified TPACK self-efficacy level was high with an overall mean score of 3.95 (SD $=0.59)$. This result indicates a large rise in student teachers' modified TPACK level of self-efficacy after engaging in CALL. In the technology-related sector, such an increase was evident. The domains of TPACK are TK (pre-CALL M $=3.23$, $\mathrm{SD}=0.85$; post-CALL $\mathrm{M}=3.73, \mathrm{SD}=0.52$ ), $\mathrm{TCK}$ (pre-CALL $\mathrm{M}=3.07, \mathrm{SD}=0.90$; post-CALL $\mathrm{M}=3.84, \mathrm{SD}=0.76$ ), TPK (pre-CALL $\mathrm{M}=2.85, \mathrm{SD}=0.87$; post-CALL $\mathrm{M}=4.01, \mathrm{SD}=0.56$ ) and TPACK (pre-CALL $\mathrm{M}=2.83, \mathrm{SD}=0.86$; post-CALL M $=4.23, \mathrm{SD}=0.68$ ).

Table 1. Community means and standard deviations for modified TPACK-EFL scale score comparisons

\begin{tabular}{llllll}
\hline \multirow{2}{*}{ Scale } & \multicolumn{3}{c}{ Pre-CALLP } & & \multicolumn{2}{c}{ Post-CALLP } \\
\cline { 2 - 3 } \cline { 5 - 6 } TK & $M$ & $S D$ & & $M$ & $S D$ \\
CK & 3.23 & 0.85 & & 3.73 & 0.52 \\
PK & 3.80 & 0.83 & 3.88 & 0.57 \\
PCK & 3.77 & 0.64 & & 3.83 & 0.51 \\
TCK & 4.06 & 0.87 & & 4.14 & 0.53 \\
TPK & 3.07 & 0.90 & & 3.84 & 0.76 \\
TPACK & 2.85 & 0.87 & & 4.01 & 0.56 \\
TPACK-EFL & 2.83 & 0.86 & & 4.23 & 0.68 \\
\hline
\end{tabular}


Note: TK= Technical Knowledge, $\mathrm{CK}=$ Content Knowledge, $\mathrm{PK}=$ Pedagogical Knowledge, $\mathrm{PCK}=$ Pedagogical Content Knowledge, TCK= Technological Content Knowledge, TPK= Pedagogical Technological Knowledge, TPACK= Pedagogical Technological Content Knowledge

Table 2. Mean score category breakdown

\begin{tabular}{ll}
\hline Means & Corresponding level \\
\hline $1.0-1.80$ & Very low \\
$1.81-2.60$ & Low \\
$2.61-3.40$ & Moderate \\
$3.41-4.20$ & High \\
$4.21-5.0$ & Very high \\
\hline
\end{tabular}

In order to address the third research question concerning the effect of CALL on the interpretation of modified TPACK self-efficacy by student teachers of English, the paired-samples t-test was performed on the overall impressions of the pre- and post-CALL TPACK-EFL questionnaire by the participants. The result of the $t$-test and effect size indicates that the difference in the perceived total self-efficacy of student teachers on the pre- and post-CALL modified TPACK-EFL questionnaire was statistically important, $\mathrm{t}=22,680, \mathrm{p}<.001, \mathrm{r}=$ .411. (see Tables $3 \& 4$ ). The null hypothesis will accordingly be dismissed. This means that CALL could have helped student teachers tremendously to increase their TPACK efficacy level for English language instruction. In addition, the findings of the t-test showed that the difference obtained in the perceived self-efficacy of student teachers on the modified TPACK-EFL subscales was statistically important only in the TPACK technology-related domains, namely TK, TCK, TPK, and TPACK (see Figure F3).

Table 3. Significant difference between the pre- and post-CALL perceived general TPACK self-efficacy of student teachers

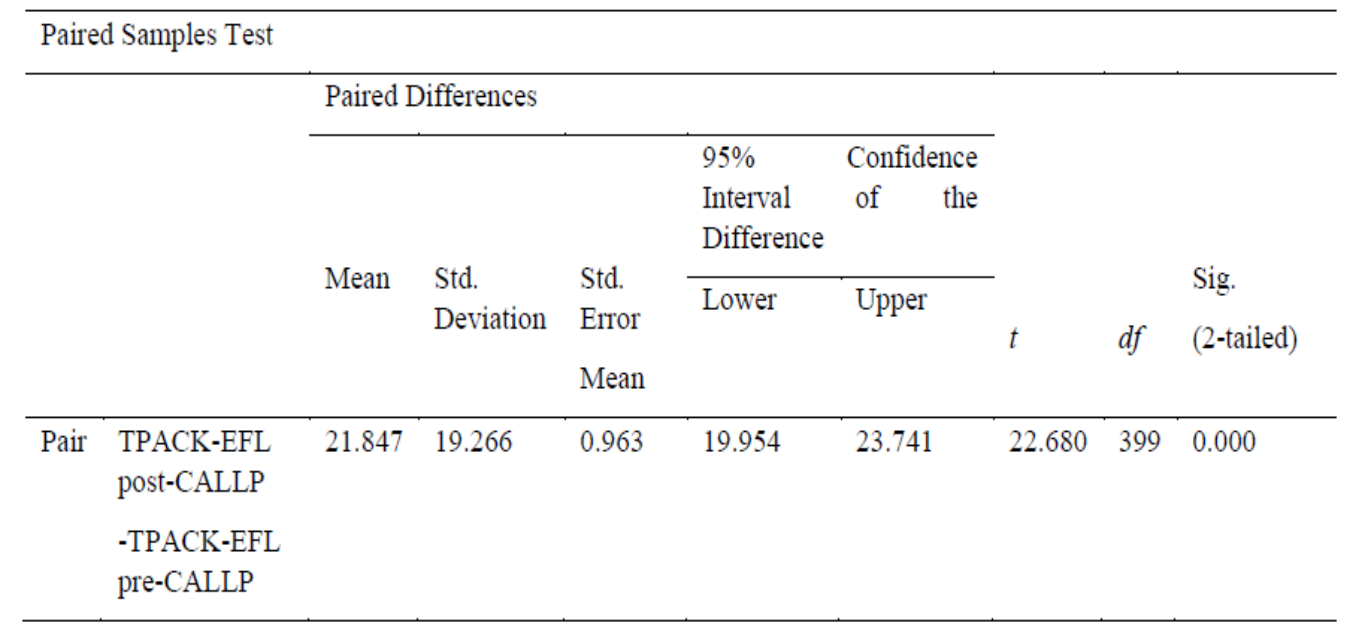

Table 4. Effect size on student teachers perceived overall TPACK self-efficacy

\begin{tabular}{lc}
\hline Cohen's $d$ & Corresponding $r$ \\
\hline$d=.90$ & $r=.41$ \\
\hline
\end{tabular}




\section{Findings from Interviews}

Regarding the fourth research question, there were seven emerging themes for student teachers' TPACK selfefficacy change: Positive CALL impact, CALL integration models, exposure to various pedagogy-oriented technology tools, hands-on experience with content fine-tuning technology tools, technology knowledge enhancement, inconsistency of ELTEP technology courses with students' needs, and ELTEP's limited CALL use (see Table 5).

The first theme, CALL positive effect, represents the satisfaction of student teachers with CALL. Nearly 91 percent of the participants shared optimistic CALL impressions. Participants were engaged in CALL sessions fraught with up-to-date expertise and skills during the workshops. Such exposure to the new CALL seemed to have a positive effect on the overall impressions of CALL by participants with regard to their confidence and competence in TPACK.

The second, third, fourth, and fifth themes discuss the improvement in self-efficacy of student teachers with reference to TPACK, TPK, TCK, and TK, respectively, supporting the results of the TPACK-EFL study. The second theme, models of CALL integration, refers to the TPACK benefit of student teachers by modeling CALL use. Around 88 percent of respondents said the models presented in CALL workshops helped them boost their self-efficacy with TPACK. The third theme, exposure to different pedagogy-oriented technology tools, is defined as the TPK benefit of student teachers by exposure to various technology tools for educational purposes. Slightly more than $81 \%$ of the participants thought that their TPK had been strengthened by the variety of educational technology resources offered in CALL. The fourth subject, handson experience with fine-tuning content technology tools, describes the TCK benefit of student teachers by experiencing CALL tools for manipulating content for ELT. Seventy-five percent of respondents identified that trying CALL content manipulation technology techniques led to improving their TCK. The fifth theme, enhancement of technology skills, denotes the TK benefit of student teachers by learning new concepts and applications of technology. Nearly $72 \%$ of the participants interpreted their increased self-efficacy of TK as by learning new technical concepts and skills in CALL, the effects of their experience are learned.

Further, the sixth and seventh themes provide insights into the incorporation of technology courses and CALL in ELTEPs. The sixth theme, the inconsistency between ELTEP technology courses and the needs of students, represents the frustration of student teachers with ELTEP technology courses. Approximately $66 \%$ of the respondents expressed their concern that in order to prepare them to incorporate CALL into their future EL classes, the technology courses offered in their ELTEPs are not enough. Finally, the seventh theme, the restricted CALL usage of ELTEP, stands for the inadequate exposure of student teachers to CALL in ELTEP. Slightly more than $59 \%$ of participants reported that the use of CALL by their teacher educators is restricted to simple computer software and applications such as presentation using MS PowerPoint and internet browser to access genuine and non-authentic language content. 
Table 5. Attribution to student teachers' TPACK self-efficacy change

\begin{tabular}{|c|c|c|c|c|c|c|}
\hline Theme & & Definition & & $f$ & $\%$ & Sample quotation \\
\hline $\begin{array}{l}\text { Positive } \\
\text { impact }\end{array}$ & CALLP & $\begin{array}{l}\text { Student } \\
\text { satisfaction } \\
\text { CALLP }\end{array}$ & $\begin{array}{r}\text { teachers' } \\
\text { with }\end{array}$ & 29 & 90.63 & “ \\
\hline
\end{tabular}

$\begin{array}{lll}\text { CALL integration } & \text { Student teachers' 28 87.50 } & \text { "Well, after observing the models provided } \\ \text { models } & \text { TPACK gain through } & \text { in the intensive workshops for the four skills } \\ \text { of English, I can tell you that I feel more } & \text { competent in using different computer } \\ & & \text { programs in my method of teaching } \\ & & \text { English." }\end{array}$

CALLP workshops have exposed us to a lot of ideas, concepts, and skills of technology use for EFL teaching, we weren't aware of! Besides, I feel more confident in using technology now than before. And I feel really glad that I attended all of the workshops."

Exposure to various pedagogy-oriented technology tools
Student teachers' TPK gain through exposure to different technology tools for instructional purposes
$26 \quad 81.25$

"Getting to know many educational computer programs and how they can be used in teaching, I believe that my knowledge has improved. And, since we have many options in terms of computer programs, we can properly choose and employ various programs as part of the methodology to make English classes more fun."

Hands-on
experience with
content fine-tuning
technology tools

Student teachers' TCK $24 \quad 75.00$ gain through experiencing CALL tools for creating, modifying EFL content

Student teachers' TK $23 \quad 71.88$ gain through learning new technology concepts \& applications
"The new programs that we have tried in the workshops to create and modify content made me feel more prepared to use technology to modify content to suit my lesson objectives and present it to the class in a more interesting way."

"Through CALLP, we had the chance to get acquainted with new computer applications and technical terms such as Second Life, Moodle, LMS, VOIP, etc." 


$\begin{array}{lrlrr}\text { Inconsistency of } & \text { Student teachers' 21 } 65.63 \\ \text { ELTEP technology } & \text { dissatisfaction with } & \\ \text { courses with } & \text { ELTEP technology } & \\ \text { students' needs } & \text { courses }\end{array}$

ELTEP's limited Student teachers' $19 \quad 59.38$

CALL use

inadequate exposure to

CALL in ELTEP
"Frankly, I feel that I need more training regarding CALL. The computer course that we had is not enough because it is technical! I mean basic things that we already knew, like how to create a file, how to access a file and a website, how to create a document, etc. For the educational technology course, well, it is general and is not really linked to EFL teaching. Other students from other departments take the same two courses."

\section{DISCUSSION}

\section{Impact of CALL}

The first research question of the present study was, "What are the perceptions of the Indian student teachers of English of their TPACK self-efficacy pre-CALL with reference to CK, PK, PCK, TK, TCK, TPK, and TPACK TPACK domains?" Student teachers had a self-reported moderate level of pre-CALL TPACK selfefficacy in all TPACK domains based on the quantitative data findings, except for PCK, which was viewed as a high level. This result indicates that ELTEPs is typical and adapted to the PCK of Shulman (2016).

The second research question was, "What are the perceptions of the Indian student teachers of their postCALL TPACK self-efficacy regarding the TPACK domains of CK, PK, PCK, TK, TCK, TPK, and TPACK?" "Student teachers report a high-to-very-high degree of post-CALL TPACK self-efficacy in all TPACK's technologyrelated domains, according to quantitative findings. This finding was supported by the results of the interview repeated by the student in relation to the technology-related domains of TPACK, teachers' selfefficacy shifts. This finding emphasizes that while CALL was short-term, it allows student teachers to increase their knowledge and skills in the integration of advanced technology in ELTEPS.

The third research question was, "Is there any significant difference in the perceived overall TPACK selfefficacy pre-and post-CALL of Indian student teachers of English?" "The related result showed that the null hypothesis proposed was dismissed. In other words, there is a major difference in the perceived overall TPACK pre- and post-CALL self-efficacy of student teachers of English. Only in the technology-related domains of TPACK, namely TK, TCK, TPK and TPACK, was such a statistically significant difference evident. Such a finding was substantiated by expressed satisfaction and the perceived positive impact of CALL, expressed by most of the interviewees, especially on TPACK's technology-related domains. This result indicates that CALL has a positive impact on the TPACK self-efficacy of student teachers. In this regard, the results showed that while most student teachers had a moderate level of perceived pre-CALL overall selfefficacy of TPACK, after taking part in CALL, they represented a significantly high perceived overall selfefficacy of TPACK. In the technology-related domains of TPACK, namely TK, TCK, TPK, and TPACK, such an improvement was important. In the realm of EFL, these results are in line with Ersanli (2016), Joo et al. (2018), and Tseng et al. (2019), that in the growth of their EFL-TPACK skills, CALL training had a positive effect on EFL student teachers.

\section{Attributions of Increased TPACK Self-Efficacy}

The fourth research question was, "What are the attributions of Indian English language student teachers to their increased or decreased perceptions of self-efficacy with TPACK?" "The related qualitative findings indicated that student teachers perceived that it was not gratifying for the technology courses offered in their ELTEPs and the exposure to CALL instruments to make them feel ready to use CALL. CALL has helped student 
teachers to foster their understanding in this respect. Similar results have been reported in EFL by Akayoğlu (2017), Hlas (2017), Ince (2017), Jeong (2017), Kwangsawad (2016), Mei et al. (2017), Tai (2015), and Turgut and Boylan (2017) that proper CALL training is important to help EFL teachers establish positive beliefs about their self-efficacy in TPACK because they need to feel relaxed and competent in using CALL.

\section{Implications and Recommendations}

The results of this study suggest an urgent need for student teachers whether in ESL or EFL settings to increase understanding and further TPACK effectiveness so that they are competently encouraged to use CALL and its instruments, which are impressively smarter on the day. Not only by up-to-date CALL workshops but also through getting as part of ELTEP a CALL-dedicated course by day. In reality, the effectiveness of TPACK has influenced the intention of student teachers to adopt and use CALL for future EFL instruction (Alşler \& Yıldırım, 2018; Joo et al., 2018; Mei et al., 2017; Rahimi \& Pourshahbaz, 2019). If CALL is expected to be adopted and used by these student teachers in their vocation, ELTEP policymakers should take serious action to educate and raise awareness of CALL among non-native English language student teachers pedagogically, and not just educate them about technology, it is also strongly recommended that a CALL course be implemented into the ELTEP apprenticeship.

In addition, teacher educators are models for their students, and their systematic use of numerous ELTEP CALL resources offers excellent visibility and measurable experience. In this way, they contribute positively to improving the self-efficacy of TPACK for their students (Admiraal et al., 2016; El Shaban \& Egbert, 2018; Hlas, 2017; Tseng et al., 2019). Teacher educators should therefore use various CALL instruments in their classes to allow student teachers to observe the use of CALL.

\section{CONCLUSION}

The aim of this research was to explore the effects of CALL on the self-efficacy of the TPACK of _Indian student teachers of English. The modified TPACK-EFL scale results and interviews indicated a major increase in the overall TPACK self-efficacy of student teachers of English after participating in CALL. The change was noticeable in TPACK's technology-related domains (i.e., TK, TCK, TPK, and TPACK). This study generally demonstrates that TPACK CALL preparation holds great promise for student teachers of English in both ESL and EFL settings and the incorporation of CALL into ELTEPs is highly recommendable. Also, after engaging in CALL workshops, student teachers' TPACK self-efficacy increased. It can be suggested on the basis of the findings of this study that while CALL integration is paramount in ELTEPs, student teachers of English need various hands-on opportunities and a kind of internship to promote their self-efficacy with TPACK to be in a better position to use technology correctly and efficiently to the benefit of their learners.

\section{Study Limitations and Suggestions for Further Research}

There were two drawbacks to this report. First, depending on participants' self-reporting of their TPACK selfefficacy pre- and post-CALL, it employed a one-group pre-test-post-test configuration. It will help to determine the general results from this research by replicating this study using a pre-test-post-test control and experimental group configuration. Second, in the ELTEPs of India, it was restricted to student teachers. If this research had targeted teacher educators at the same ELTEPs, the results would have been distinct. A related research on the perceptions of TPACK self-efficacy of teacher educators is also suggested for further review.

\section{REFERENCES}

Akayoğlu, S. (2017). Perceptions of pre-service English teachers towards computer assisted language learning course. Illkögrretim Online, 16(3), 1220-1234. doi: 10.17051/ilkonline.2017.330252

Al-Ahdal, A. A. M. H. \& Alqasham, F. H. (2020). Saudi EFL Learning and Assessment in Times of Covid-19: Crisis and beyond. Asian EFL Journal, 356-383.

Al-Ahdal, A. A. M. H. (2020). Translanguagism and the Bilingual EFL Learner of Saudi Arabia: Exploring New Vistas. Asian EFL Journal, 27(1), 14-26.

Alfallaj, F. S. S. (2020). Technology in Saudi EFL Undergraduate Classrooms: Learning Tool or Weapon of Distraction? The Asian ESP Journal, 16 (4), 97-115. 
Alotumi, M. (2020). EFL learning beyond the wall with MALL: College students' perceptions. In R. Ahmed, A. Alkadi, \& T. Hagar (Eds.), Enhancements and limitations to ICT-based informal language learning: Emerging research and opportunities (pp. 138-160). IGI Global.

Bandura, A. (1994). Self-efficacy. In V. S. Ramachaudran (Ed.), Encyclopedia of human behavior (Vol. 4, pp. 7181). Academic Press.

Baser, D., Kopcha, T. J., \& Ozden, M. Y. (2015). Developing a technological pedagogical content knowledge (TPACK) assessment for pre-service teachers learning to teach English as a foreign language. Computer Assisted Language Learning, 29(4), 749-764. https://doi.org/10.1080/09588221.2015.1047456

Beatty, K. (2010). Teaching and researching computer-assisted language learning (2nd ed.). Pearson Education Limited.

Bostancıoğlu, A., \& Handley, Z. (2018). Developing and validating a questionnaire for evaluating the EFL 'Total PACKage': Technological pedagogical content knowledge (TPACK) for English as a foreign language (EFL). Computer Assisted Language Learning, 31(5-6), 572-598. https://doi.org/10.1080/09588221.2017.1422524

Chambers, A., \& Bax, S. (2006). Making CALL work: Towards normalization. System, 34(4), 465-479. https://doi.org/10.1016/j.system.2006.08.001

Cohen, J. (1992). A power primer. Psychological Bulletin, 112(1), 155-159. https://doi.org/10.1037/00332909.112.1.155

Cohen, L., Manion, L., \& Morrison, K. (2018). Research methods in education (8th ed.). Routledge.

Creswell, J. W., \& Creswell, J. D. (2018). Research design: Qualitative, quantitative, and mixed methods approaches (5 ed.). SAGE Publication, Inc.

Cumming, G. (2012). Understanding the new statistics: Effect sizes, confidence intervals, and meta-analysis. Routledge.

El Shaban, A., \& Egbert, J. (2018). Diffusing education technology: A model for language teacher professional development in CALL. System, 78, 234-244. https://doi.org/10.1016/j.system.2018.09.002

Ersanli, C. Y. (2016). Improving technological pedagogical content knowledge (TPACK) of pre-service English language teachers. International Education Studies, 9(5), 18-27. https://doi.org/10.5539/ies.v9n5p18

Fathi, J., \& Ebadi, S. (2020). Exploring EFL pre-service teachers' adoption of technology in a CALL program: obstacles, motivators, and maintenance. Education and Information Technologies, 25(5), 3897-3917. https://doi.org/10.1007/s10639-020-10146-y

Hlas, A. (2017). Student teachers and CALL: Personal and pedagogical uses and beliefs. Calico Journal, 34(3), 336- 354. https://doi.org/10.1558/cj.26968

İnce, M. N. (2017). The analysis of EFL teachers' perceptions of CALL and variables influential on teachers' attitudes. Journal of Narrative and Language Studies, 5(8), 59-72.

İşler, C., \& Ylldırım, O. (2018). Perceptions of Turkish pre-service EFL teachers on their technological pedagogical content knowledge. Journal of Education and Future, 13, 145-160. https://search.proquest.com/openview/6e177c91c29fcc0d1c9c93023d6dc20b/1.pdf?pqorigsite= gscholar\&cbl=2030900

Joo, Y. J., Park, S., \& Lim, E. (2018). Factors influencing pre-service teachers' intention to use technology: TPACK, teacher self-efficacy, and technology acceptance model. Educational Technology \& Society, 21(3), 48-59. https://www.jstor.org/stable/26458506

Kartchava, E., \& Chung, S. (2015). Pre-service and in-service English as a second language teachers' beliefs about the use of digital technology in the classroom. Studies in English Language Teaching, 3(4), 355383. https://doi.org/10.22158/selt.v3n4p355

Kent, A. M., \& Giles, R. M. (2017). Pre-service teachers' technology self-efficacy. SRATE Journal, 26(1), 9-20. https://eric.ed.gov/?id=EJ1134392

Kessler, G. (2018). Technology and the future of language teaching. Foreign Language Annals, 51(1), 205-218. https://doi.org/10.1111/flan.12318

Kessler, G., \& Hubbard, P. (2017). Language teacher education and technology. In C. A. Chapelle \& S. Sauro (Eds.), The handbook of technology and second language teaching and learning (pp. 278-292). Wiley. https://doi.org/10.1002/9781118914069.ch19

Kitishat, A. R., Al Omar, K. H., \& Al Momani, M. A. K. (2020). The Covid-19 crisis and distance learning: Eteaching of language between reality and challenges. The Asian ESP Journal, 316-326.

Koehler, M. J., Mishra, P., \& Cain, W. (2017). What is technological pedagogical content knowledge (TPACK)? Journal of Education, 193(3), 13-19. https://doi.org/10.1177/002205741319300303 
Koh, J. H. L. (2011). Computer skills instruction for pre-service teachers: A comparison of three instructional approaches. Computers in Human Behavior, 27(6), 2392-2400. https://doi.org/10.1016/j.chb.2011.08.002

Koh, J. H. L., \& Chai, C. S. (2014). Teacher clusters and their perceptions of technological pedagogical content knowledge (TPACK) development through ICT lesson design. Computers \& Education, 70, 222-232. https://doi.org/10.1016/j.compedu.2013.08.017

Kwangsawad, T. (2016). Examining EFL pre-service teachers' TPACK trough self-report, lesson plans and actual practice. Journal of Education and Learning, 10(2), 103-108. doi: 10.11591/edulearn.v10i2.3575

Lai, C., Shum, M., \& Tian, Y. (2014). Enhancing learners' self-directed use of technology for language learning: the effectiveness of an online training platform. Computer Assisted Language Learning, 29(1), 40-60. https://doi.org/10.1080/09588221.2014.889714

Le, N., \& Song, J. (2018). TPACK in a CALL course and its effect on Vietnamese pre-service EFL teachers. Asian EFL Journal, 20(9-1), 31-56.

Lee, K., Yan, A., \& Joshi, K. (2011). Understanding the dynamics of users' belief in software application adoption. International Journal of Information Management, 31(2), 160-170. https://doi.org/10.1016/j.ijinfomgt.2010.07.009

Luanganggoon, N. (2020). Content and Language Integrated Learning (CLIL) Teaching Practices in Thailand Higher Education. The Asian ESP Journal, 16 (4), 233-258.

Magulod Jr, G. C. (2019). Learning Styles, Study Habits and Academic Performance of Filipino University Students in Applied Science Courses: Implications for Instruction. Journal of technology and science education, 9(2), 184-198.

Mei, B., Brown, G. T. L., \& Teo, T. (2017). Toward an understanding of pre-service English as a foreign language teachers' acceptance of computer-assisted language learning 2.0 in the People's Republic of China. Journal of Educational Computing Research, 56(1), 74-104. https://doi.org/10.1177/0735633117700144

Mishra, P., \& Koehler, M. J. (2006). Technological pedagogical content knowledge: A framework for teacher knowledge. Teachers College Record, 108(6), 1017-1054. https://www.learntechlib.org/p/99246/

Mohammadzadeh, B., \& Salem, N. (2018). A study on the integration of ICT by EFL teachers in Libya. Eurasia Journal of Mathematics, Science and Technology Education, 14(7), 2787-2801. https://doi.org/10.29333/ejmste/90594

Omidvar, R. \& Ravindranath, B. K. (2017). Position of English in India: Three-way categorization. Language in India. www.languageinindia.com

Park, M., \& Son, J. B. (2020). Pre-service EFL teachers' readiness in computer-assisted language learning and teaching. Asia Pacific Journal of Education, 1-15. https://doi.org/10.1080/02188791.2020.1815649

Pegrum, M. (2014). Mobile learning: Languages, literacies and cultures. Palgrave Macmillan. https://doi.org/10.1057/9781137309815

Prasojo, L. D., Mukminin, A., Habibi, A., Marzulina, L., Sirozi, M., \& Harto, K. (2018). Learning to teach in a digital age: ICT integration and EFL student teachers' teaching practices. The Journal of Teaching English with

Schmid, E. (2017). Teacher education in computer-assisted language learning. Bloomsbury Academic. https://doi.org/10.5040/9781474292788

Setyowati Ciptaningrum, D. (2017). The development of the survey of technology use, teaching, and technologyrelated learning experiences among pre-service English language teachers in Indonesia. Journal of Foreign Language Teaching and Learning, 2(2), 11-26. https://doi.org/10.18196/ftl.2220

Shulman, L. S. (2016). Those who understand: Knowledge growth in teaching. Educational Researcher, 15(2), 4-14. https://doi.org/10.3102/0013189x015002004

Son, J. B. (2018). Teacher development in technology-enhanced language teaching. Springer. https://doi.org/10.1007/978-3-319-75711-7

Tai, S. J. D. (2013). From TPACK-in-action workshops to English classrooms: CALL competencies developed and adopted into classroom teaching [Doctoral dissertation, Iowa State University]. ISU Digital Repository https://lib.dr.iastate.edu/etd/13335

Tai, S. J. D. (2015). From TPACK-in-action workshops to classrooms: CALL competency developed and integrated. Language Learning \& Technology, 19(1), 139-164. https://www.researchgate.net/publication/268147286_From_TPACK-inaction_ workshops_to_classrooms_CALL_competency_developed_and_integrated 
Technology, 18(3), 18-32. https://www.tewtjournal.org/?wpdmact=process\&did=NTQ1LmhvdGxpbms Rahimi, M., \& Pourshahbaz, S. (2019). English as a foreign language teachers' TPACK. IGI Global. https://doi.org/10.4018/978-1-5225-6267-2

Teo, T., Sang, G., Mei, B., \& Hoi, C. K. W. (2018). Investigating pre-service teachers' acceptance of Web 2.0 technologies in their future teaching: A Chinese perspective. Interactive Learning Environments, 27(4), 530- 546. https://doi.org/10.1080/10494820.2018.1489290

Torsani, S. (2016). CALL teacher education: Language teachers and technology integration. Sense Publishers. https://www.springer.com/gp/book/9789463004770

Tseng, J. J., Cheng, Y. S., \& Yeh, H. N. (2019). How pre-service English teachers enact TPACK in the context of web-conferencing teaching: A design thinking approach. Computers \& Education, 128, 171-182. https://doi.org/10.1016/j.compedu.2018.09.022

Turgut, Y., \& Boylan, M. (2017). Tracing pre-service English language teachers' perceived TPACK in sophomore, junior, and senior levels. Cogent Education, 4(1), 1-20. https://doi.org/10.1080/2331186x.2017.1368612 